\title{
Paracrystalline Cell Wall Surface Layers of Different Bacillus stearothermophilus Strains
}

\author{
PAUL MESSNER, ${ }^{1}$ FRIEDRICH HOLLAUS, ${ }^{2}$ AND UWE B. SLEYTR ${ }^{1 *}$ \\ Zentrum für Ultrastrukturforschung, Universität für Bodenkultur, A-1180 Vienna ${ }^{1}$ and Österreichisches Zuckerforschungs- \\ Institut, A-2286 Fuchsenbigl, ${ }^{2}$ Austria
}

\begin{abstract}
We compared the protein and glycoprotein patterns of 39 Bacillus stearothermophilus strains of various origins by sodium dodecyl sulfate-polyacrylamide gel electrophoresis. The ultrastructures of the cell walls of intact cells were examined by freeze-etching, negative-staining, and thin-sectioning techniques. A total of 30 strains possessed a paracrystalline protein or glycoprotein surface layer (S-layer) which resembled the highest-molecular-weight band(s) on the electrophoretograms. We found a remarkable heterogeneity in the molecular weights of the S-layer subunits and the geometry and constants of the S-layer lattices, even among closely related strains. All of the strains examined were equally susceptible to lysozyme, indicating that the S-layers have pores at least $3.5 \mathrm{~nm}$ wide.
\end{abstract}

Paracrystalline cell wall surface layers (S-layers) are present on a wide range of gram-positive and gram-negative eubacteria and archaebacteria $(4,9,32,33,35,36,42)$. Highresolution electron microscopic studies have revealed that these layers completely cover the cell surface and have hexagonal, square, and oblique lattices. The morphological units composed of hexamers, tetramers, or dimers exhibit center-to-center spacings ranging from 5 to $20 \mathrm{~nm}$.

Chemical analyses of the S-layers have shown that they are composed of protein or glycoprotein subunits with molecular weights ranging from approximately 40,000 to 200,000 . Self-assembly experiments with isolated S-layer subunits have demonstrated that the information for the geometry of the lattices and for the orientation of the regular arrays on intact cells is determined by the molecular structure and the directional bonds of the lattice protomers, not by the underlying cell wall or envelope layer onto which the subunits assemble. The assembly and free rearrangement on the cell surface are entropy-driven processes and result in the formation of a closed, highly ordered protein meshwork during cell growth. Thus, the paracrystalline S-layers on bacterial cells can be considered the simplest protein membranes developed during evolution.

Compared with the considerable amount of knowledge on the structure, chemistry, and assembly processes of Slayers, very little is known about their functional significance. Like other bacterial cell wall surface structures, they most likely evolved as a consequence of selective pressures generated by the interactions between the cells and their environment. As recently reviewed (36), the information available so far indicates that closed S-layers have the potential to function as (i) barriers against external or internal factors, (ii) supporting protein frameworks involved in maintaining the shape of the cells in organisms which possess no rigid envelope layer, and (iii) promoters for surface recognition and cell adhesion. In conclusion, it appears that a universal functional principle does not exist.

Most of the studies on the structure, chemistry, assembly, and function of S-layers have been done by using single, selected strains of a given species. Comparative studies on the existence of S-layers in individual strains of a species have been performed only for Clostridium thermohydrosul-

\footnotetext{
* Corresponding author.
}

furicum, Clostridium thermosaccharolyticum (12), Bacillus sphaericus (44), Pseudomonas sp. (16, 17), and Aquaspirillum serpens $(5 \mathrm{a}, 40 \mathrm{a})$.

In this paper we describe studies on the distribution and characterization of paracrystalline S-layers in 39 strains of Bacillus stearothermophilus from different habitats.

\section{MATERIALS AND METHODS}

Bacterial strains, The strains used in this study are listed in Table 1 . The isolates from deep sea sediments were identified as B. stearothermophilus on the basis of the following morphological, biochemical, and physiological characteristics: rods 0.5 to 1.0 by 2 to $3.5 \mu \mathrm{m}$; spores ellipsoidal and subterminal; sporangia swollen; positive reactions for catalase (strain 20-M was negative), citrate (strains 20-M and 21$M$ were negative), and casein hydrolysis (strains $20-\mathbf{M}$ and $25-\mathrm{M}$ were negative); growth at $65^{\circ} \mathrm{C}$; and negative reactions for anaerobic growth, the Voges-Proskauer test, growth in 5 and $7 \% \mathrm{NaCl}$, growth at $\mathrm{pH} 5.7$ (strain $25-\mathrm{M}$ was positive), growth in $0.02 \%$ azide broth, hydrolysis of starch (strains 20 $\mathbf{M}$ and 21-M were positive), utilization of propionate, reduction of $\mathrm{NO}_{3}{ }^{-}$to $\mathrm{NO}_{2}{ }^{-}$, and decomposition of tyrosine.

Chemicals. The growth media were obtained from Difco Laboratories, Detroit, Mich., and Oxoid Ltd., Basingstoke, United Kingdom. Lyșozyme was obtained from Serva, Heidelberg, Federal Republic of Germany, and the protease inhibitors were from Sigma Chemical Co., St. Louis, Mo. All other chemicals were of analytical grade and commercially available.

Growth conditions. The bacteria were first grown on $S$ VIII agar plates (1) at $60^{\circ} \mathrm{C}$. S-VIII medium contained $10.0 \mathrm{~g}$ of Bacto-Peptone (Difco), $5.0 \mathrm{~g}$ of yeast extract (Oxoid), $5.0 \mathrm{~g}$ of Lab-Lemco powder (Oxoid), $0.6 \mathrm{~g}$ of sucrose, $1.3 \mathrm{~g}$ of $\mathrm{K}_{2} \mathrm{HPO}_{4} \cdot 3 \mathrm{H}_{2} \mathrm{O}, 0.1 \mathrm{~g}$ of $\mathrm{MgSO}_{4} \cdot 7 \mathrm{H}_{2} \mathrm{O}, 0.01 \mathrm{~g}$ of $\mathrm{FeSO}_{4} \cdot 7 \mathrm{H}_{2} \mathrm{O}$, and 1 liter of distilled water, and the $\mathrm{pH}$ of this medium was 7.0 to 7.2 . Erlenmeyer flasks $(300 \mathrm{ml})$ containing $50 \mathrm{ml}$ of S-VIII medium were inoculated from the plates and were incubated overnight at $60^{\circ} \mathrm{C}$. Portions $(2 \mathrm{ml})$ of the resulting bacterial suspensions were transferred into 300 -ml flasks containing $50 \mathrm{ml}$ of S-VIII medium, and these preparations were grown for $8 \mathrm{~h}$ at $60^{\circ} \mathrm{C}$ in a GFL water bath (shaking frequency, 100 cycles per min). The contents of the flasks were used immediately for the studies described below. All subsequent procedures were performed at $4^{\circ} \mathrm{C}$ unless indicated otherwise. 
TABLE 1. Designations and sources of the B. stearothermophilus strains used in this study

\begin{tabular}{|c|c|c|}
\hline Strain & Source $^{a}$ & Origin \\
\hline S65-67 & 1 & Beet sugar factory \\
\hline PV72 & 1 & Beet sugar factory \\
\hline E24-66 & 1 & Beet sugar factory \\
\hline $\mathrm{H} 7.65$ & 1 & Beet sugar factory \\
\hline H5-65 & 1 & Beet sugar factory \\
\hline B26-66 & 1 & Beet sugar factory \\
\hline S41-66 & 1 & Beet sugar factory \\
\hline S51-66 & 1 & Beet sugar factory \\
\hline S61-67 & 1 & Beet sugar factory \\
\hline H3-65 & 1 & Beet sugar factory \\
\hline H4-65 & 1 & Beet sugar factory \\
\hline H13-66 & 1 & Beet sugar factory \\
\hline H15-66 & 1 & Beet sugar factory \\
\hline H6-65 & 1 & Beet sugar factory \\
\hline L6-65 & 1 & Beet sugar factory \\
\hline E8-65 & 1 & Beet sugar factory \\
\hline E36-66 & 1 & Beet sugar factory \\
\hline L32-65 & 1 & Beet sugar factory \\
\hline NCA 1503 & 2 & \\
\hline ATCC $12980^{\mathrm{T}}$ & 3 & \\
\hline D11-66 & 1 & Beet sugar factory \\
\hline E23-66 & 1 & Beet sugar factory \\
\hline E4-65 & 1 & Beet sugar factory \\
\hline E21-66 & 1 & Beet sugar factory \\
\hline B23-66 & 1 & Beet sugar factory \\
\hline B24-66 & 1 & Beet sugar factory \\
\hline NRS 2004/3a & 4 & \\
\hline NRS $1536 / 3 c$ & 4 & \\
\hline NRS $106 / 1 b_{2}$ & 4 & \\
\hline NCTC 10003 & 5 & \\
\hline $20-\mathrm{M}$ & 1 & Deep-sea sediment $b$ \\
\hline $21-\mathrm{M}$ & 1 & Deep-sea sediment ${ }^{b}$ \\
\hline $24-\mathrm{M}$ & 1 & Deep-sea sediment ${ }^{b}$ \\
\hline $25-\mathrm{M}$ & 1 & Deep-sea sediment ${ }^{b}$ \\
\hline 26-M & 1 & Deep-sea sediment ${ }^{b}$ \\
\hline $27-\mathrm{M}$ & 1 & Deep-sea sediment ${ }^{b}$ \\
\hline $31-\mathrm{M}$ & 1 & Deep-sea sediment \\
\hline 104-M & 1 & Deep-sea sediment ${ }^{b}$ \\
\hline $112-\mathrm{M}$ & 1 & Deep-sea sediment ${ }^{b}$ \\
\hline
\end{tabular}

${ }^{a}$ 1, F. Hollaus, Österreichisches Zuckerforschungs-Institut, Fuchsenbigl, Austria; 2, National Canners' Association, Washington, D.C.; 3, ATCC, American Type Culture Collection, Rockville, Md.; 4, N. R. Smith Collection maintained by R. E. Gordon, American Type Culture Collection, Rockville, Md.; 5, National Collection of Type Cultures, London, England.

${ }^{b}$ Sample 72 from the 2nd POLA Expedition of the AustroHungarian Navy in 1891 (18). Depth, $1,838 \mathrm{~m} ; 35^{\circ} 59^{\prime} 30^{\prime \prime} \mathrm{N}, 25^{\circ} 8^{\prime} 20^{\prime \prime} \mathrm{E}$ (station 92).

${ }^{c}$ Sample 81. Depth $2,524 \mathrm{~m} ; 35^{\circ} 50^{\prime} 30^{\prime \prime} \mathrm{N}, 27^{\circ} 12^{\prime} 20^{\prime \prime} \mathrm{E}$ (station 106).

Preparation of cell walls and S-layers. The S-layers were prepared exactly as described by Sleytr and Glauert (34), with one exception. The cells were disrupted with a Branson model B-15P cell disruptor (Branson Sonic Power Co., Danbury, Conn.) at maximum output for $5 \mathrm{~min}$, and the cell suspension was kept at $0^{\circ} \mathrm{C}$ in an ice bath.

Treatment with inhibitors of proteases. Samples of bacteria which did not reveal a high-molecular-weight band (S-layer band) after sodium dodecyl sulfate (SDS)-polyacrylamide gel electrophoresis (PAGE) were subjected to treatment with protease inhibitors. After growing in the Erlenmeyer flasks, the bacterial suspensions were centrifuged in a Heraeus Christ Labofuge I at $5,000 \times g$ for $10 \mathrm{~min}$. The pellet from one flask was suspended in ethanol $(1.5 \mathrm{ml})$ containing phenylmethylsulfonyl fluoride $(2 \mathrm{mM})$, benzamidine $(2 \mathrm{mM})$, and 1,10-phenanthroline $(2 \mathrm{mM})$ and kept at $4^{\circ} \mathrm{C}$ for $30 \mathrm{~min}$.
Subsequently, $1.5 \mathrm{ml}$ of $50 \mathrm{mM}$ tris(hydroxymethyl)aminomethane hydrochloride (Tris- $\mathrm{HCl}$ ) buffer $(\mathrm{pH} \mathrm{7.2)} \mathrm{containing}$ $\epsilon$-amino- $n$-caproic acid $(10 \mathrm{mM})$, ethylenediaminetetraacetate $(4 \mathrm{mM})$, pepstatin $(0.02 \mathrm{mg} / \mathrm{ml})$, chymostatin $(0.02$ $\mathrm{mg} / \mathrm{ml})$, leupeptin $(0.02 \mathrm{mg} / \mathrm{ml})$, and antipain $(0.02 \mathrm{mg} / \mathrm{ml})$ was added, and the reaction mixture was kept at $4^{\circ} \mathrm{C}$ for $1 \mathrm{~h}$. After sedimentation by centrifugation at $5,000 \times g$ for 10 min, the cells were immediately subjected to the pretreatment procedures for SDS-PAGE, freeze-etching, and thin sectioning.

Lysozyme test. The bacterial suspensions without protease inhibitors were centrifuged for $10 \mathrm{~min}$ at $5,000 \times g$, and the pellets were suspended in $50 \mathrm{mM}$ Tris- $\mathrm{HCl}$ buffer $(\mathrm{pH} \mathrm{7.2)}$ at $22^{\circ} \mathrm{C}$ and diluted to an optical density at $600 \mathrm{~nm}$ of $\geq 0.600$. A lysozyme solution $(0.03 \mathrm{ml} ; 0.5 \mathrm{mg}$ of lysozyme per $\mathrm{ml}$ in 50 $\mathrm{mM}$ Tris- $\mathrm{HCl}$ buffer, $\mathrm{pH}$ 7.2) was added to $3 \mathrm{ml}$ of each bacterial suspension, and the preparations were incubated for $30 \mathrm{~min}$ at $22^{\circ} \mathrm{C}(25)$. The decrease in the optical density at $600 \mathrm{~nm}$ of each bacterial suspension with and without lysozyme was measured with a Beckman model 25 spectrophotometer, using S-VIII medium as a blank. The accompanying cell lysis was observed under phase-interference contrast by using a Reichert-Jung Polyvar microscope (Reichert AG, Wien, Austria).

SDS-PAGE. The bacterial suspensions were centrifuged for $10 \mathrm{~min}$ at $5,000 \times g$, and the resulting pellets were washed with $50 \mathrm{mM}$ Tris-HCl buffer ( $\mathrm{pH}$ 7.2). After sedimentation the samples that were not processed immediately were frozen and stored at $-20^{\circ} \mathrm{C}$. The washed cell pellets ( 40 to 50 $\mathrm{mg}$, both with and without protease inhibitors) or $10-\mathrm{mg}$ portions of isolated cell wall preparations or S-layer selfassembly products were suspended in approximately $1.2 \mathrm{ml}$ of $50 \mathrm{mM}$ Tris- $\mathrm{HCl}$ buffer ( $\mathrm{pH} \mathrm{7.2)}$, and solid SDS was added to the solutions ( $4 \mathrm{mg} / 10 \mathrm{mg}$ of cell pellet).

After boiling in a water bath for $15 \mathrm{~min}$ and cooling, the SDS-insoluble materials were removed by centrifugation. The resulting clear supernatants were withdrawn, and $0.02-$ to $0.05-\mathrm{ml}$ samples were mixed with $0.02 \mathrm{ml}$ of an equilibration buffer containing $10 \mathrm{mM}$ Tris $-\mathrm{HCl}(\mathrm{pH} \mathrm{7.2),0.02 \%}$ ethylenediaminetetraacetate, $1 \%$ SDS, $1 \%$ 2-mercaptoethanol, $10 \%$ glycerol, and $0.01 \%$ bromophenol blue and incubated for $30 \mathrm{~min}$ at $60^{\circ} \mathrm{C}$.

The gel systems used were adapted from those of Maizel (19), and the buffers used were those described by Laemmli (15). Electrophoresis was performed in a model GE-4 slab gel electrophoresis apparatus (Pharmacia, Uppsala, Sweden).

The samples $(0.03$ to $0.05 \mathrm{ml})$ were applied to slab gels $(20$ by $20 \mathrm{~cm}$ ) with $4 \%$ stacking gels and separation gels with linear gradients from 10 to 30\%. 3-Dimethylamino-propionitrile $(0.01 \%)$ was used as the catalyst (initiator) instead of $N, N, N^{\prime}, N^{\prime}$-tetramethylethylenediamine; in this way the rate of polymerization could be slowed sufficiently to allow for the preparation of the gradient (27). The samples were run at an initial current of $150 \mathrm{~mA}$, and after the samples entered the separation gel, the current was increased to $210 \mathrm{~mA}$. Bromophenol blue was used as a marker dye. Electrophoreses were terminated when the dye reached the bottom of the gels. During the procedure the temperature was kept at 10 to $12^{\circ} \mathrm{C}$. Staining with Coomassie blue G-250 was carried out overnight at $60^{\circ} \mathrm{C}$. The gels were then destained with $10 \%$ acetic acid, and photographs were taken.

For molecular weight determinations the SDS extracts were diluted with buffer to obtain sufficiently weak S-layer bands. Samples were run on slab gels $(20$ by $20 \mathrm{~cm}$ ) with $4 \%$ stacking gels and $7 \%$ separation gels at a constant current of 


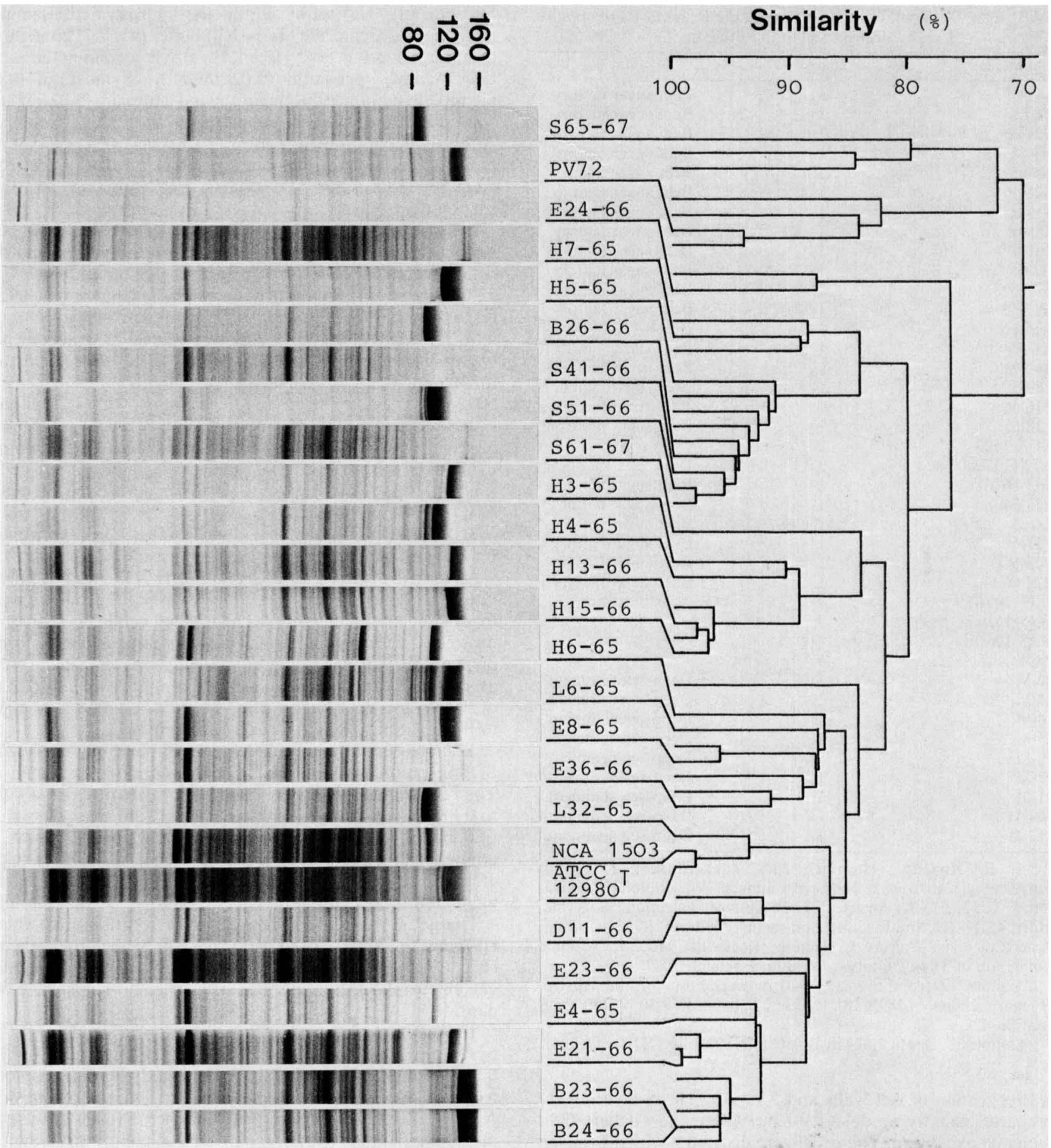

FIG. 1. SDS-PAGE of 26 SDS-solubilized B. stearothermophilus strains related to the dendrogram from Klaushofer and Hollaus (14), showing the relationships among the strains.

$210 \mathrm{~mA}$ and stained as described above. High-molecularweight calibration kits obtained from Boehringer, Mannheim, Federal Republic of Germany, and Bio-Rad Laboratories, Richmond, Calif., were used for the molecular weight determinations.

Glycoproteins were detected on small gels $(8$ by $8 \mathrm{~cm})$ with $4 \%$ stacking gels and $10 \%$ separation gels. The initial current was $80 \mathrm{~mA}$, and after the samples entered the separation gel, the current was increased to $120 \mathrm{~mA}$.
Two different periodic acid-Schiff staining procedures were used $(8,29)$. The method of Segrest and Jackson (29) was used after exhaustive removal of SDS from the gels (8). Each protein extract (obtained from at least two identically grown cultures) was analyzed in two different electrophoretic experiments.

Freeze-etching. Freeze-etching of whole cells was performed with a Balzers model $360 \mathrm{M}$ (Balzers AG, Liechtenstein) or a Bioetch model 2005 (Leybold Heraeus, Köln, 


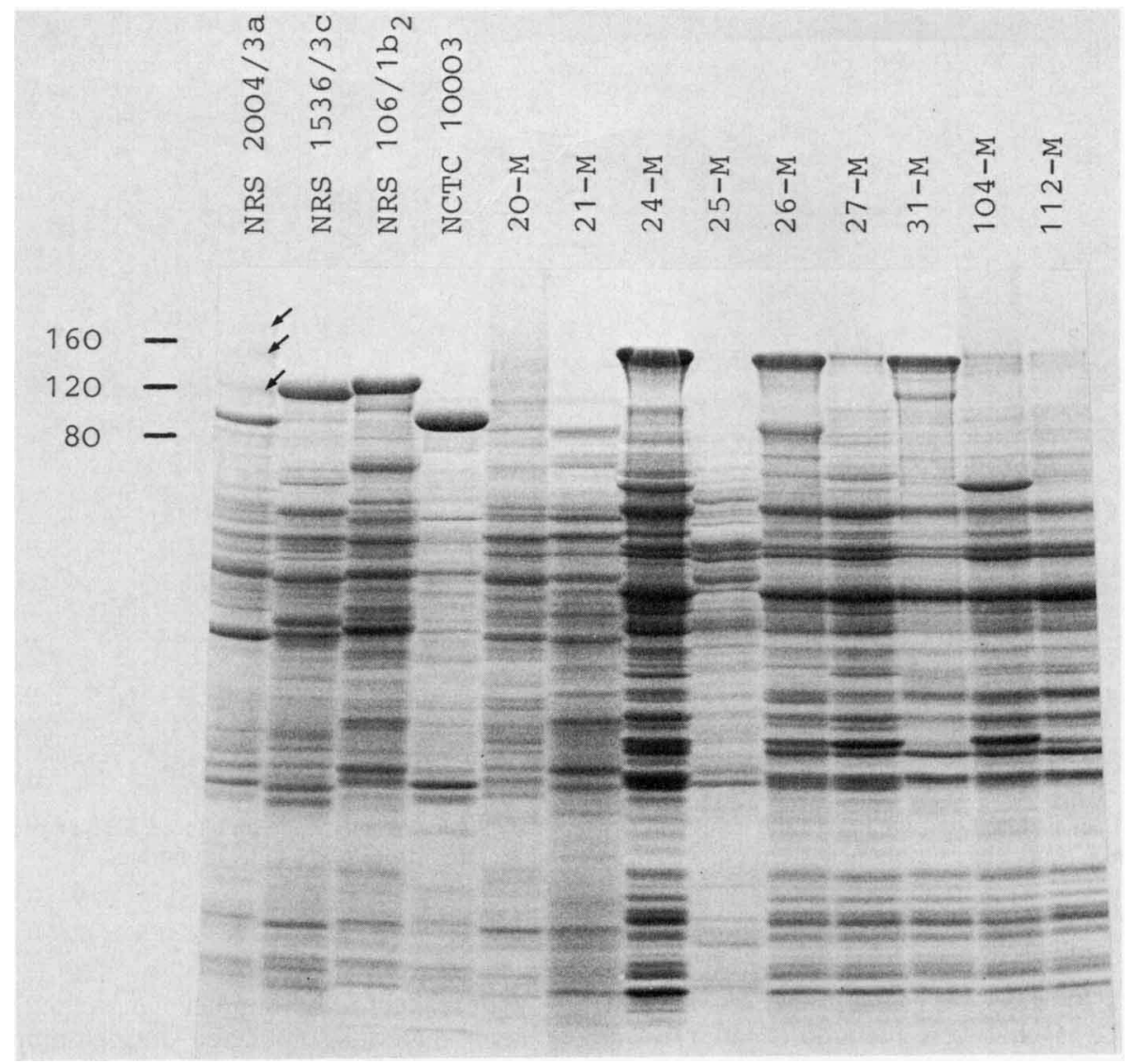

FIG. 2. SDS-PAGE of SDS-solubilized B. stearothermophilus strains, including four type culture strains and nine strains isolated from deep sea sediments.

Federal Republic of Germany) freeze-etching unit. The etching temperature was $-98^{\circ} \mathrm{C}$, and the samples were etched for $2 \mathrm{~min}$. After platinum-carbon shadowing and carbon coating the replicas were cleaned with $30 \%$ chromium oxide and picked up on uncoated copper grids.

Thin sectioning. For ultrathin sections the bacterial suspensions were centrifuged for $10 \mathrm{~min}$ at $5,000 \times \mathrm{g}$, and the resulting pellets were fixed in a $5 \%$ acrolein- $1 \%$ glutaraldehyde-0.1 M sodium cacodylate $(\mathrm{pH} \mathrm{7.0)}$ solution at room temperature for approximately $3 \mathrm{~h}$. The supernatants were discarded, and the samples were washed twice with cacodylate buffer. The cells were then fixed for $1 \mathrm{~h}$ in $1 \%$ osmium tetroxide in cacodylate buffer containing $0.2 \mathrm{mg}$ of ruthenium red per $\mathrm{ml}$ (the latter was added just before use). After fixation the pellets were washed once with the same buffer and twice with water and treated with a $1 \%$ aqueous solution of uranyl acetate for $45 \mathrm{~min}$; this was followed by two washes with water. Each preparation was then directly dehydrated with dimethoxypropane (24) and embedded in Spurr resin.

Ultrathin sections were cut with a Reichert-Jung Ultracut ultramicrotome (Reichert AG), mounted on Formvar-coated copper grids, and stained with lead citrate (28).

Negative staining. Negative staining was performed on 300-mesh copper grids by using a Formvar-supported film that was stabilized by vacuum deposition of carbon and rendered hydrophilic by glow discharge.

The grids were floated on 1 drop of a cell wall or S-layer suspension and moved into several drops of distilled water and then into another drop of negative stain. The excess fluid was removed by using filter paper. Alternatively, adsorbed specimens were chemically fixed by floating the grids on 1 drop of $2.5 \%$ glutaraldehyde in $0.1 \mathrm{M}$ sodium cacodylate buffer ( $\mathrm{pH} 7.0$ ) for $20 \mathrm{~min}$ before transfer to several drops of distilled water and the negative-staining solution. The negative stains used in this study included $2 \%$ ammonium molybdate ( $\mathrm{pH} 7.0), 1 \%$ uranyl acetate $(\mathrm{pH} 4.5)$, and $1 \%$ potassium phosphotungstate ( $\mathrm{pH} 7.0)$.

Electron microscopy. The preparations were examined with a Philips model EM 301 electron microscope (Philips, Eindhoven, The Netherlands) operated at $80 \mathrm{kV}$, and the micrographs were taken on Kodak type 5302 film. The magnification was calibrated by using a grating replica $(2,160$ lines per $\mathrm{mm}$ ).

\section{RESULTS}

Table 1 shows the designations and sources of the $39 \mathrm{~B}$. stearothermophilus strains used in this study. Of these 39 organisms, 24 were isolated from beet sugar extraction plants (F. Hollaus, Ph.D. thesis, Universität für Bodenkultur, Wien, Austria, 1969). These strains, together with the two type culture strains (strains NCA 1503 and ATCC $12980^{\mathrm{T}}$ [ $\mathrm{T}=$ type strain]) (Fig. 1), have been characterized previously by numerical taxonomy procedures (11a, 14), using the key recommended by Smith et al. (39). The strains tested for 52 unit characters showed similarity coefficients of at least $84 \%$ (Fig. 1). The other 15 strains studied (Table 1 and Fig. 2) included 6 strains from type culture collections 


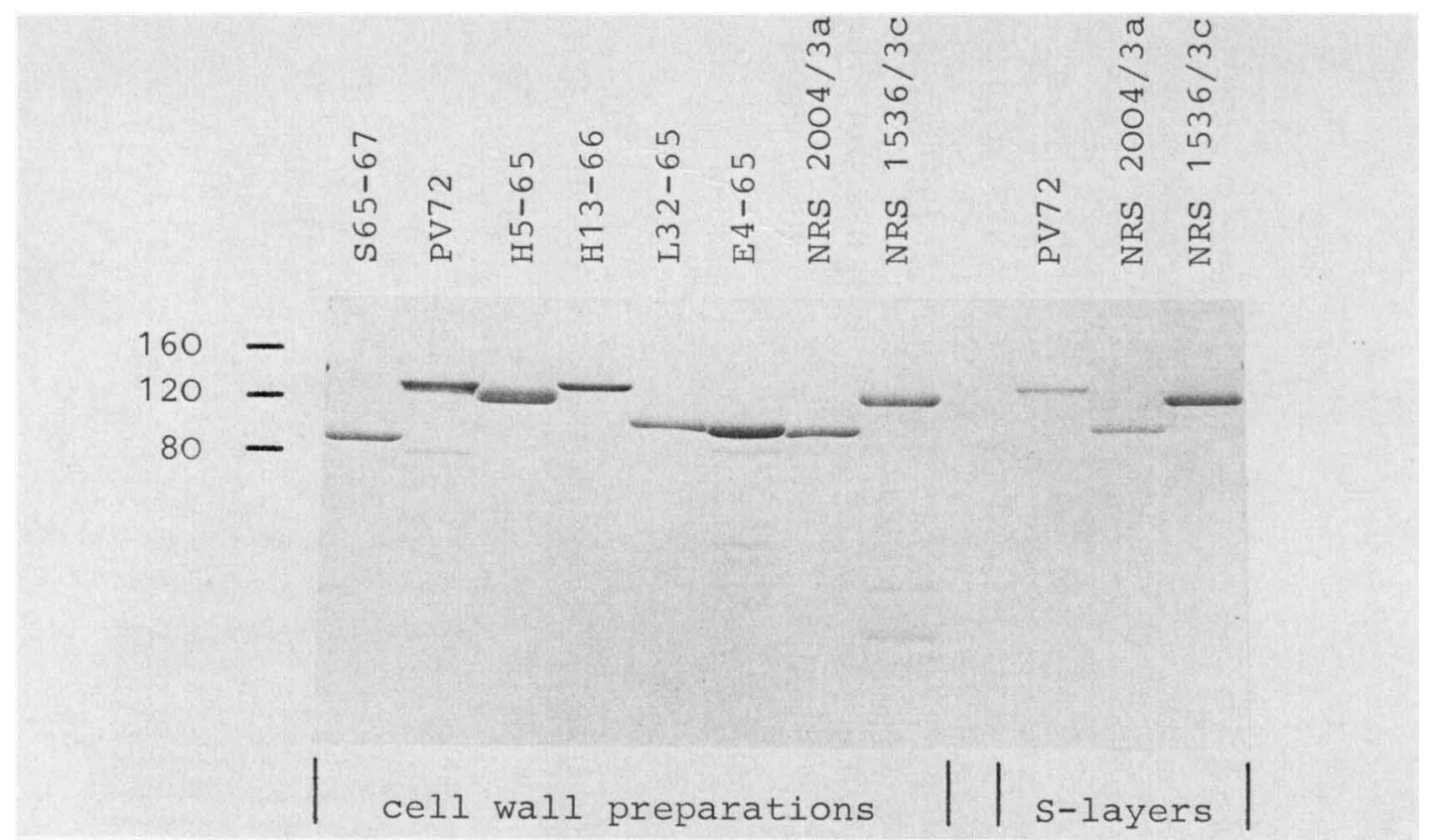

FIG. 3. SDS-PAGE of isolated cell walls of eight selected strains of $B$. stearothermophilus and three S-layer preparations representing examples of hexagonal (strain PV72), oblique (strain NRS 2004/3a), and square (strain NRS 1536/3c) lattices.

and 9 strains (strains 20-M, 21-M, 24-M, 25-M, 26-M, 27-M, $31-\mathrm{M}, 104-\mathrm{M}$, and 112-M) that were recently isolated by one of us (F.H.) from deep-sea sediments which were collected in the Mediterranean Sea in 1891 (18) and stored as dry samples under contamination-free conditions at room temperature in the dark.

The SDS-PAGE patterns of the SDS-soluble cell proteins of the 39 B. stearothermophilus strains listed in Table 1 are shown in Fig. 1 and 2. Despite the taxonomic similarity of the strains considered in Fig. 1, the protein patterns in the electrophoretograms reveal considerable heterogeneity. In most patterns the highest-molecular-weight band shown represents the major component. By comparing a few of these patterns with the electrophoretograms of both the cell wall preparations and the guanidine hydrochloride extracts of the cell walls $(34,38)$ of the corresponding organisms, we concluded that these highest-molecular-weight bands represent the $S$-layer proteins.

For illustration, the characteristic protein patterns of the cell wall and S-layer preparations from a selected number of strains are shown in Fig. 3. This slab gel also demonstrates that the S-layer protein(s) represents the major cell wall protein(s). The S-layer of strain NRS 2004/3a yielded four protein bands (Fig. 2). The 93-kilodalton band was the major component, and, compared with the three weak, highermolecular-weight bands $(120,147$, and 170 kilodaltons $)$, this band did not stain with the periodic acid-Schiff reagent. Cell wall and S-layer preparations isolated in the presence of protease inhibitors revealed identical patterns of bands. The S-layer preparations of strain ATCC $12980^{\mathrm{T}}$ gave two protein bands (120 and 125 kilodaltons), whereas the S-layers of all other strains examined (Table 2) correlated with a single band. With the exception of the three high-molecular-weight S-layer bands of strain NRS 2004/3a and the S-layer band of strain PV72, the S-layer bands of all other organisms gave ambiguous periodic acid-Schiff reactions. Clear differences with respect to both molecular weight and the amount of Slayer material solubilized during sample preparation were observed (Fig. 1 and 2). As summarized in Table 2, the apparent molecular weights of the S-layer promoters varied between 83,000 and 170,000 (the gels used for determining apparent molecular weights are not shown).

The electrophoretic protein profiles of 12 strains exhibited only weak S-layer bands or no S-layer bands after protein staining (Fig. 1 and 2). When the isolation was performed in the presence of inhibitors of proteases, increases or changes in the apparent molecular weights of these bands were not observed. Strains 20-M, 21-M, E23-66, and E36-66, which yielded no protein bands or only very vague protein bands in the range characteristic for S-layer bands, clearly displayed lattices in freeze-etched preparations and well-defined Slayers in thin sections cut perpendicular to the cell wall (Fig. 4d).

Freeze-etched preparations were also used for identifying the type of S-layer lattice and the center-to-center spacing between the morphological units (Table 2). With the exception of strain PV72, which had a hexagonally ordered S-layer (Fig. 4c), the strains displayed square (Fig. 4a) and oblique (Fig. 4b) lattices. As Table 2 shows, the dimensions of the oblique and square lattices comprised two clusters, with average dimensions for the square lattice of approximately 14.0 and $10.6 \mathrm{~nm}$ and average dimensions for the oblique lattice of approximately 11.6 by 8.6 and 8.4 by $5.6 \mathrm{~nm}$.

The negative-staining techniques used in this study frequently gave no indication of a periodic cell wall surface structure. The S-layers that were clearly visible in freezeetched preparations frequently had a random granular appearance on negatively stained images. With some S-layer or cell wall preparations the structure of the periodic arrays was better preserved by including the chemical fixation step in the negative-staining schedule.

Exponentially grown cultures of all of the strains listed in 
TABLE 2. Presence and characteristics of crystalline S-layers on B. stearothermophilus cell walls

\begin{tabular}{|c|c|c|c|c|c|}
\hline Strain & SDS-PAGE & Freeze-etching & Type of lattice ${ }^{a}$ & Spacing $(\mathrm{nm})^{b}$ & $M_{\mathrm{r}}\left(\times 10^{3}\right)^{c}$ \\
\hline S65-67 & + & + & $S$ & 10.2 & 84 \\
\hline PV72 & + & + & $\mathrm{H}$ & 17.9 & 130 \\
\hline E24-66 & $-d$ & - & & & \\
\hline $\mathrm{H} 7-65$ & $-d$ & - & & & \\
\hline H5-65 & + & + & $\mathrm{O}$ & $8.6 / 5.7$ & 116 \\
\hline B26-66 & + & + & $\mathrm{O}$ & $11.8 / 9.1$ & 93 \\
\hline$S 41-66$ & $-^{d}$ & - & & & \\
\hline S51-66 & + & + & S & 14.2 & 105 \\
\hline S61-67 & $-^{d}$ & - & & & \\
\hline H3-65 & + & + & $S$ & 14.1 & 121 \\
\hline H4-65 & + & + & $\mathrm{S}$ & 14.3 & 110 \\
\hline H13-66 & + & + & $\mathrm{s}$ & 12.8 & 128 \\
\hline H15-66 & + & + & $S$ & 15.1 & 133 \\
\hline H6-65 & + & + & $S$ & 10.6 & 105 \\
\hline L6-65 & + & + & $S$ & 13.0 & 138 \\
\hline E8-65 & + & + & $\mathrm{O}$ & $11.7 / 8.6$ & 128 \\
\hline E36-66 & $( \pm)^{d}$ & + & $\mathrm{S}$ & 10.9 & 98 \\
\hline L32-65 & + & + & $\mathrm{O}$ & $11.9 / 8.6$ & 96 \\
\hline NCA 1503 & + & + & $\mathrm{O}$ & $12.2 / 9.4$ & 95 \\
\hline ATCC $12980^{\mathrm{T}}$ & + & + & $\mathrm{O}$ & $9.5 / 5.2$ & 120,125 \\
\hline D11-66 & $-{ }^{d}$ & - & & & \\
\hline E23-66 & $( \pm)^{d}$ & - & & & \\
\hline E4-65 & + & + & $\mathrm{S}$ & 10.8 & 97 \\
\hline E21-66 & + & + & $S$ & 15.3 & 127 \\
\hline B23-66 & + & + & $\mathrm{S}$ & 14.2 & 158 \\
\hline B24-66 & + & + & $S$ & 13.3 & 158 \\
\hline NRS 2004/3a & $+^{d}$ & + & $\mathrm{O}$ & $11.1 / 8.5$ & $93,120,147,170$ \\
\hline NRS $1536 / 3 c$ & + & + & $\mathrm{S}$ & 13.8 & 121 \\
\hline NRS $106 / 1 b_{2}$ & + & + & $\mathrm{S}$ & 14.4 & 124 \\
\hline NCTC 10003 & + & + & $\mathrm{O}$ & $11.7 / 7.6$ & 97 \\
\hline $20-\mathrm{M}$ & $( \pm)^{d}$ & + & $\mathrm{O}$ & $11.4 / 9.4$ & 142 \\
\hline $21-\mathrm{M}$ & $( \pm)^{d}$ & + & $\mathrm{O}$ & $7.5 / 6.1$ & 83 \\
\hline 24-M & + & + & $\mathrm{O}$ & $7.9 / 5.5$ & 145 \\
\hline $25-\mathrm{M}$ & $-{ }^{d}$ & - & & & \\
\hline $26-M$ & + & + & $\mathrm{O}$ & $10.8 / 7.7$ & 140 \\
\hline 27-M & + & + & $\mathrm{O}$ & $11.0 / 7.5$ & 146 \\
\hline $31-\mathrm{M}$ & + & + & $\mathrm{O}$ & $12.6 / 9.1$ & 138 \\
\hline $104-M$ & $-{ }^{d}$ & - & & & \\
\hline $112-\mathrm{M}$ & $-{ }^{d}$ & - & & & \\
\hline
\end{tabular}

${ }^{a} \mathrm{~S}$, Square; $\mathrm{H}$, hexagonal; O, oblique.

${ }^{b}$ Center-to-center spacing of the morphological units in the lattice (from freeze-etched preparations).

${ }^{c} M_{\mathrm{r}}$ values represent the means of three independent determinations.

${ }^{d}$ Isolated in the presence of protease inhibitors.

Table 1 were equally susceptible to lysozyme. This was confirmed by the decreases in the optical densities of the bacterial suspensions and by light microscopic observations, which revealed no intact cells $30 \mathrm{~min}$ after lysozyme was added to the cultures.

\section{DISCUSSION}

Paracrystalline protein or glycoprotein cell wall S-layers are very common features of procaryotic cells, including many species of the Bacillaceae $(4,6,36,44)$. To obtain information about the distribution and uniformity of S-layers in $B$. stearothermophilus, a representative number of strains from distinct habitats, including six strains from type culture collections, were chosen for this study. Our results show that a great majority of strains possess paracrystalline cell wall S-layers and that the S-layers of the positive strains display remarkable heterogeneity with respect to the type of lattice and with respect to the molecular weight of the constituent subunits. All three common types of lattices (square, oblique, and hexagonal) found in bacterial cell walls $(36,37 a)$ were represented. A similar heterogeneity in the types of lattices was previously described in a study on the S-layers of Pseudomonas acidovorans, which showed that this gram-negative species includes strains with hexagonally or tetragonally ordered arrays $(16,17)$. On the other hand, in a study on the taxonomy and fine structure of hyperthermophilic, saccharolytic clostridia ( $C$. thermosaccharolyticum and $C$. thermohydrosulfuricum), it was demonstrated that the type of S-layer lattice is a characteristic taxonomic feature of each species (12).

In our experience the freeze-etching technique has been the most reliable method for detecting S-layers, particularly when no distinct, high-molecular-weight S-layer band is revealed by SDS-PAGE. The weak S-layer bands in otherwise well-defined SDS-PAGE protein patterns of whole cell extracts are probably due to poor solubility of the S-layer materials in SDS rather than to proteolytic effects, since the presence of protease inhibitors did not lead to changes in the intensities and apparent molecular weights of the S-layer bands. With most strains the paracrystalline arrays, although clearly visible in freeze-etched preparations, could not be demonstrated by common negative-staining techniques (in- 

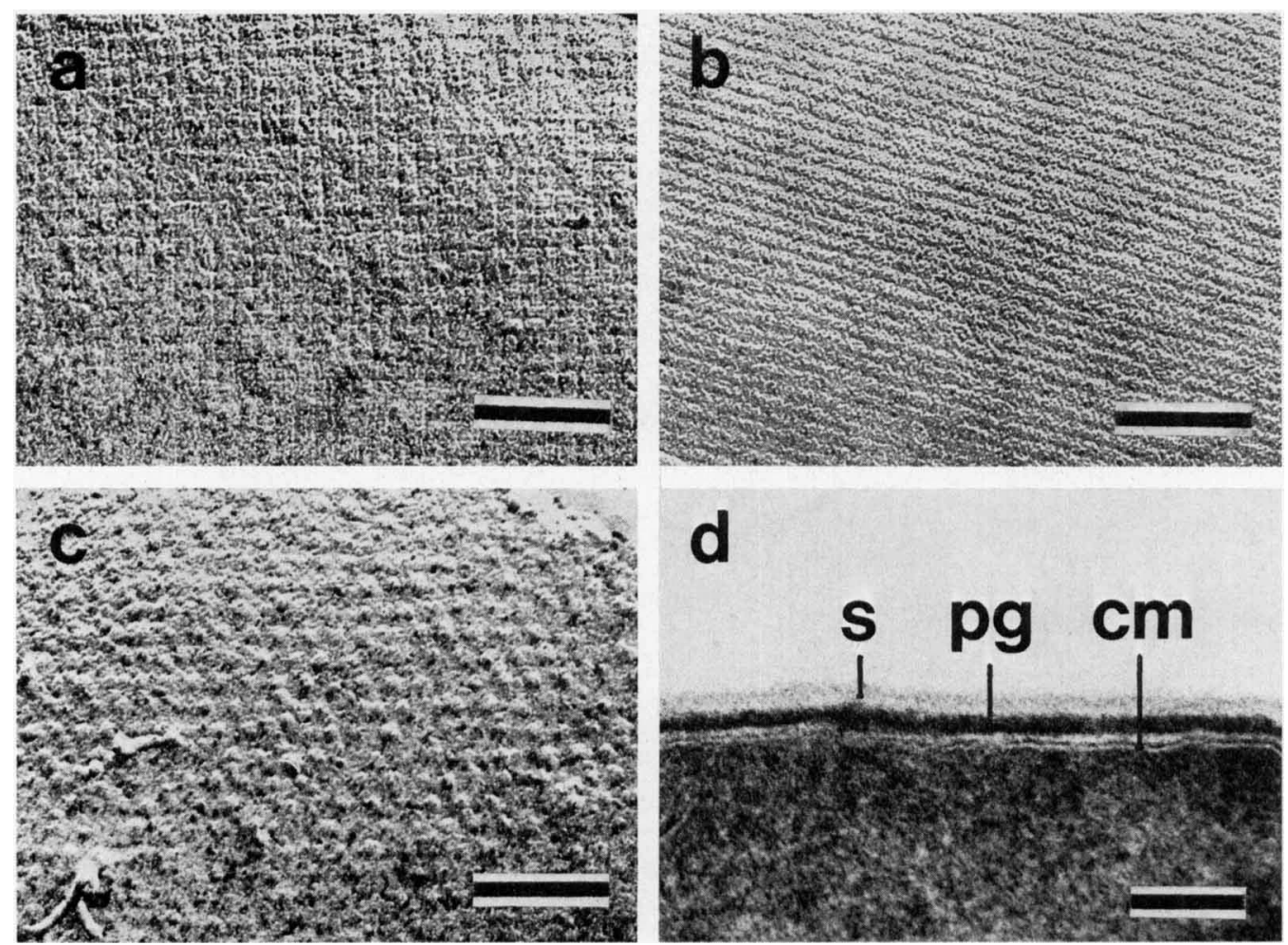

FIG. 4. Freeze-etched preparations of intact cells of B. stearothermophilus strains H4-65 (a), NRS 2004/3a (b), and PV72 (c). (d) Electron micrograph of an ultrathin section of the cell envelope of strain PV72. s, S-layer; pg, peptidoglycan, cm, cytoplasmic membrane. Bars $=100$ nm.

cluding uranyl acetate, phosphotungstate acid, and ammonium molybdate). With some strains the periodic arrays could be visualized when the cell wall preparations were chemically fixed with glutaraldehyde before negative staining. Thus, the S-layers of $B$. stearothermophilus appear to be very delicate protein structures which are easily denatured or collapse under non-physiological conditions. Only the controlled dehydration of the frozen protein meshwork in the course of the freeze-etching procedure appears to preserve the paracrystalline arrays. In a recent study on the distribution of cell wall S-layers among 61 strains of B. sphaericus, the occurrence of strains with regularly and nonregularly structured S-layers was reported (44). Since for the demonstration of S-layers unfixed cell wall preparations were negatively stained, it appears likely that the nonregularly structured S-layers observed were paracrystalline arrays that were denatured in the course of the staining procedure. This interpretation is supported by our observation that the subunits of the nonregularly structured S-layers are capable of reassembly into characteristic layers on both surfaces of the cell walls from which they had been removed. Such selfassembly and reattachment capabilities of isolated S-layer subunits have been described for many other gram-positive bacteria $(4,10,11,21,30,31,33$, 43; R. Plohberger, Ph.D. thesis, Universität für Bodenkultur, Wien, Austria, 1980).

Despite the great variations in the apparent molecular weights of the S-layer subunits among different strains of $B$. stearothermophilus, the amino acid compositions of the $S$ layers of four selected strains (strains PV72, NRS 2004/3a, NRS 1536/3c, and E4-65) exhibit great similarities. The paracrystalline arrays, including hexagonal, square, and oblique lattices, are composed predominantly of acidic ami- no acids (36) and thus resemble most $S$-layers found in other gram-positive and gram-negative bacteria $(2,3,7,13,20,22$, 23, 41; C. M. Henry, Ph.D. thesis, University of Pittsburgh, Pittsburgh, Pa., 1972). Our observation that, with two exceptions (strains PV72 and NRS 2004/3a), the S-layer bands gave no clear positive periodic acid-Schiff reaction does not exclude the possibility that the other paracrystalline arrays are composed of glycoprotein subunits. The negative periodic acid-Schiff reaction may be explicable simply by the presence of short or branched carbohydrate chains or by the fact that only few cis-diol groupings are present in the carbohydrate residues, which are known to be attacked more rapidly than the trans-diol groupings (5).

Relatively little is known about the specific functions of $S$ layers. Because of their surface location and the fact that they completely cover the cell, it can be assumed that they must play an important role in the interaction between the cells and their environment $(4,36)$. The biological significance of S-layers is further indicated by the fact that, in order to maintain these outermost envelope layers, a particular protein (or glycoprotein) species has to be produced in larger amounts than any other class of protein in the cell. Like other bacterial surface structures, the ability to synthesize S-layers can be lost under laboratory conditions which do not mimic the natural, and consequently competitive, habitats. Such selection phenomena may explain why nine strains that lacked the ability to synthesize S-layers were identified in this study. The reason for the heterogeneity in S-layers among different strains of $B$. stearothermophilus and the biological significance of this observation cannot be fully explained yet. It is tempting to speculate that despite this diversity the S-layers of all of the strains examined 
perform similar functions. By analogy with other bacterial surface structures (e.g., lipopolysaccharides of gram-negative species), the S-layers appear to be nonconservative, macromolecular structures which co-evolutionarily adapt to the changing environmental pressures of the particular habitat of the organism.

Considering S-layers as protective coats that limit or prevent the passage of hostile components or attack by natural predators, it is interesting to observe that the $S$ layers of all of the B. stearothermophilus strains examined are permeable to lysozyme. This shows that the pores in the protein meshwork are at least $3.5 \mathrm{~nm}$ wide (26). Our observation makes it likely that the S-layers of $B$. stearothermophilus have a function different from protection of the cell wall from lytic enzymes, as suggested for S-layers of Sporosarcina ureae $(40)$ and other gram-positive bacteria $(32,34)$.

Our results also strongly indicate that paracrystalline protein layers on gram-positive organisms are not involved in determining cell shape, as suggested by Hastie and Brinton $(10,11)$. The cells of the $B$. stearothermophilus strains with and without $S$-layers which we examined in this study displayed identical dimensions, and, as previously shown, the induced loss of the ability to synthesize $S$-layer in strain PV72 did not lead to changes in the overall morphology of the cells (37; J. Eder, Ph.D. thesis; Universität für Bodenkultur, Wien, Austria, 1983).

\section{ACKNOWLEDGMENTS}

We are very grateful to J. Eder for confirming several tests and to F. M. Unger for critical reading of the manuscript. The deep-sea sediments were kindly provided by F. Rögl, Geologisch-Paläontologische Abteilung des Naturhistorischen Museums, Vienna, Austria.

P.M. and U.B.S. acknowledge the support of Austrian Fonds zur Förderung der wissenschaftlichen Forschung, Projekt 4483.

\section{LITERATURE CITED}

1. Bartelmus, W., and F. Perschak. 1957. Schnellmethode zur Keimzahlbestimmung in der Zuckerindustrie. Z. Zuckerind. 7:276-281.

2. Baumeister, W., F. Karrenberg, R. Rachel, A. Engel, B. ten Heggeler, and W. O. Saxton. 1982. The major cell envelope protein of Micrococcus radiodurans (R1). Structural and chemical characterization. Eur. J. Biochem. 125:535-544.

3. Beveridge, T. J. 1979. Surface arrays on the wall of Sporosarcina ureae. J. Bacteriol. 139:1039-1048.

4. Beveridge, T. J. 1981. Ultrastructure, chemistry, and function of the bacterial wall. Int. Rev. Cytol. 72:229-317.

5. Bobbitt, J. M. 1956. Periodate oxidation of carbohydrates. Adv. Carbohydr. Chem. 11:1-41.

5a.Buckmire, F. L. A., and R. G. E. Murray. 1976. Substructure and in vitro assembly of the outer, structured layer of Spirillum serpens. J. Bacteriol. 125:290-299.

6. Burley, S. K., and R. G. E. Murray. 1983. Structure of the regular surface layer of Bacillus polymyxa. Can. J. Microbiol. 29:775-780.

7. Evenberg, D., and B. Lugtenberg. 1982. Cell surface of the fish pathogenic bacterium Aeromonas salmonicida. II. Purification and characterization of a major cell envelope protein related to autoagglutination, adhesion and virulence. Biochim. Biophys. Acta 684:249-254.

8. Fairbanks, G., T. L. Steck, and D. F. H. Wallach. 1971. Electrophoretic analysis of the major polypeptides of the human erythrocyte membrane. Biochemistry 10:2606-2617.

9. Glauert, A. M., and M. J. Thornley. 1969. The topography of the bacterial cell wall. Annu. Rev. Microbiol. 23:159-198.

10. Hastie, A. T., and C. C. Brinton, Jr. 1979. Isolation, characterization, and in vitro assembly of the tetragonally arrayed layer of Bacillus sphaericus. J. Bacteriol. 138:999-1009.

11. Hastie, A. T., and C. C. Brinton, Jr. 1979. Specific interaction of the tetragonally arrayed protein layer of Bacillus sphaericus with its peptidoglycan sacculus. J. Bacteriol. 138:1010-1021.

11a.Hollaus, F., and H. Klaushofer. 1970. Taxonomische Untersuchungen an hochthermophilen Bacillus-Stämmen aus Zuckerfabriksäften. Spisy Prirodoved. Fak. Univ. J. E. Purkyne Brne K47:99-105.

12. Hollaus, F., and U. B. Sleytr. 1972. On the taxonomy and fine structure of some hyperthermophilic saccharolytic clostridia. Arch. Mikrobiol. 86:129-146.

13. Kay, W. W., J. T. Buckley, E. E. Ishiguro, B. M. Phipps, J. P. L. Monette, and T. J. Trust. 1981. Purification and disposition of a surface protein associated with virulence of Aeromonas salmonicida. J. Bacteriol. 147:1077-1084.

14. Klaushofer, H., and F. Hollaus. 1970. Zur Taxonomie der hochthermophilen, in Zuckerfabriksäften vorkommenden aeroben Sporenbildner. Z. Zuckerind. 20:465-470.

15. Laemmli, U. K. 1970 . Cleavage of structural proteins during the assembly of the head of bacteriophage T4. Nature (London) 227:680-685.

16. Lapchine, L. 1976. Ultrastructure de la paroi de Pseudomonas acidovorans. J. Microsc. Biol. Cell. 25:67-72.

17. Lapchine, L. 1979. Regularly arranged structures on the surface of some Pseudomonas sp. FEMS Microbiol. Lett. 5:223-225.

18. Luksch, J., and J. Wolf. 1892. Physikalische Untersuchungen im östlichen Mittelmeer, I und II. Reise S.M. Schiffes "Pola" in den Jahren 1890 und 1891, p. 64. In Denkschriften der kaiserlichen Akademie der Wissenschaften, Mathematisch-Naturwissenschaftliche Classe, vol. 59. K.k.Hof- und Staatsdruckerei, Wien.

19. Maizel, J. V., Jr. 1971. Polyacrylamide gel electrophoresis of viral proteins. Methods Virol. 5:179-246.

20. Marshall, C. L., A. J. Wicken, and A. D. Brown. 1969. The outer layer of the cell envelope of Halobacterium halobium. Can. J. Biochem. 47:71-74.

21. Masuda, K., and T. Kawata. 1980. Reassembly of the regularly arranged subunits in the cell wall of Lactobacillus brevis and their reattachment to cell walls. Microbiol. Immunol. 24:299308.

22. Mescher, M. F., and J. L. Strominger. 1976. Purification and characterization of a prokaryotic glycoprotein from the cell envelope of Halobacterium salinarium. J. Biol. Chem. 251:2005-2014.

23. Michl, H., D.-C. Neugebauer, and D. Oesterhelt. 1980. The 2-d crystalline cell wall of Sulfolobus acidocaldarius, p. 27-35. In W. Baumeister and W. Vogell (ed.), Electron microscopy at molecular dimensions. Springer-Verlag, Berlin.

24. Muller, L. L., and T. J. Jacks. 1975. Rapid chemical dehydration of samples for electron microscopic examination. J. Histochem. Cytochem. 23:107-110.

25. Neujahr, H. Y., B. Börstad, and I.-M. Logardt. 1973. Factors affecting the resistance of Lactobacillus fermenti to lysozyme. J. Bacteriol. 116:694-698.

26. Phillips, D. C. 1966. The three-dimensional structure of an enzyme molecule. Sci. Am. 215:78-90.

27. Podsulo, J. F. 1981. Glycoprotein molecular-weight estimation using sodium dodecyl sulfate-pore gradient electrophoresis: comparison of Tris-glycine and Tris-borate-EDTA buffer systems. Anal. Biochem. 114:131-139.

28. Reynolds, E. S. 1963 . The use of lead citrate at high $\mathrm{pH}$ as an electron-opaque stain in electron microscopy. J. Cell Biol. 17:208-212.

29. Segrest, J. P., and R. L. Jackson. 1972. Molecular weight determination of glycoproteins by polyacrylamide gel electrophoresis in sodium dodecyl sulfate. Methods Enzymol. 28:54-63.

30. Sleytr, U. B. 1975. Heterologous reattachment of regular arrays of glycoproteins on bacterial surfaces. Nature (London) 257:400-402.

31. Sleytr, U. B. 1976. Self-assembly of the hexagonally and tetragonally arranged subunits of bacterial surface layers and their reattachment to cell walls. J. Ultrastruct. Res. 55:360-377.

32. Sleytr, U. B. 1978. Regular arrays of macromolecules on bacterial cell walls: structure, chemistry, assembly and function. Int Rev. Cytol. 53:1-64. 
33. Sleytr, U. B. 1981. Morphopoietic and functional aspects of regular protein membranes present on prokaryotic cell walls, $p$ 3-26. In O. Kiermayer (ed.), Cytomorphogenesis in plants. Cell biology monographs, vol. 8. Springer-Verlag, Vienna.

34. Sleytr, U. B., and A. M. Glauert. 1976. Ultrastructure of the cell walls of two closely related clostridia that possess different regular arrays of surface subunits. J. Bacteriol. 126:869-882.

35. Sleytr, U. B., and A. M. Glauert. 1982. Bacterial cell walls and membranes, p. 41-76. In J. R. Harris (ed.), Electron microscopy of proteins, vol. 3. Academic Press, Inc., London.

36. Sleytr, U. B., and P. Messner. 1983. Crystalline surface layers on bacteria. Annu. Rev. Microbiol. 37:311-339.

37. Sleytr, U. B., P. Messner, D. Pum, and J. Eder. 1982. Struktur und Morphopoese periodischer Proteinmembranen bei Bakterien. Mikroskopie 39:215-232.

37a.Sleytr, U. B., P. Messner, P. Schiske, and D. Pum. 1982. Periodic surface structures on prokaryotic cells. Proc. 10th Int. Congr. Electron Microsc. Hamburg 3:1-8.

38. Sleytr, U. B., and K. J. I. Thorne. 1976. Chemical characterization of the regularly arranged surface layers of Clostridium thermosaccharolyticum and Clostridium thermohydrosulfuricum. J. Bacteriol. 126:377-383.

39. Smith, N. R., R. E. Gordon, and F. E. Clark. 1952. Aerobic sporeforming bacteria, p. 47-49. In Agriculture monograph no. 16. U.S. Department of Agriculture, Washington, D.C.

40. Stewart, M., and T. J. Beveridge. 1980 . Structure of the regular surface layer of Sporosarcina ureae. J. Bacteriol. 142:302-309.

40a.Stewart, M., and R. G. E. Murray. 1982. Structure of the regular surface layer of Aquaspirillum serpens MW5. J. Bacteriol. 150:348-357.

41. Thompson, B. G., R. G. E. Murray, and J. F. Boyce. 1982. The association of the surface array and the outer membrane of Deinococcus radiodurans. Can. J. Microbiol. 28:1081-1088.

42. Thorne, K. J. I. 1977. Regularly arranged protein on the surfaces of gram-negative bacteria. Biol. Rev. 52:219-234.

43. Tsuboi, A., N. Tsukagoshi, and S. Udaka. 1982. Reassembly in vitro of hexagonal surface arrays in a protein-producing bacterium, Bacillus brevis 47. J. Bacteriol. 151:1485-1497.

44. Word, N. S., A. A. Yousten, and L. Howard. 1983. Regularly structured and non-regularly structured surface layers of Bacillus sphaericus. FEMS Microbiol. Lett. 17:277-282. 